Gut, 1972, 13, 220-224

\title{
Hypersplenism in Wilson's disease
}

\author{
G. THOMAS STRICKLAND, ${ }^{1}$ N-K. CHANG, AND WILLIAM M. BECKNER ${ }^{2}$
}

From the Departments of Clinical Investigation and Medical Physics, US Naval Medical Research Unit No. 2, Taipei, Taiwan, Republic of China

SUMMARY Thirteen patients with Wilson's disease were compared with seven cirrhotic and 13 normal controls to define better the haematological abnormalities in this condition. Hypersplenism (anaemia, leukopenia, thrombocytopenia, and reduced red cell survival) commonly occurred in patients with both Wilson's disease and cirrhosis. These abnormalities correlated with splenic enlargement. Despite reduced haematocrits, red cell mass was greater in these two groups than in normal controls. Plasma volume and the body haematocrit/peripheral haematocrit ratios were also greater in patients with Wilson's disease and cirrhosis. Increased splenic sequestration of ${ }^{51} \mathrm{Cr}$-tagged red blood cells was not demonstrated in any subjects. The hypersplenism in patients with Wilson's disease is similar to that found in patients with cirrhosis from other causes.

Splenomegaly and pancytopenia are common in Wilson's disease, a rare hereditary illness with an excessive burden of copper in the body. Patients with Wilson's disease have cirrhosis of the liver, a condition in which hypersplenism is frequent. Haemolytic anaemia has also been reported in Wilson's disease (McIntyre, Clink, Levi, Cumings, and Sherlock, 1967).

To gain further insight into the association of pancytopenia and splenomegaly, routine haematological tests, red cell mass and survival with ${ }^{51} \mathrm{Cr}$ tagged red blood cells, and plasma volume with ${ }^{125}$ I-tagged albumin were performed on 13 patients with Wilson's disease, and the findings were compared with those of seven patients with cirrhosis of the liver and 13 normal controls. External monitoring was performed over the spleen after the injection of ${ }^{51} \mathrm{Cr}$-tagged RBCs to detect any splenic sequestration of RBCs. Results of all these studies were correlated with splenic size as estimated by palpation and percussion.

\section{Materials and Methods}

\section{SUBJECTS}

All subjects were Chinese natives of Taiwan. The 13 patients with Wilson's disease were aged 11 to 48 (average 19.6) years and included six males (Table I).

\footnotetext{
${ }^{1}$ Present address: London School of Hygiene and Tropical Medicine, Keppel and Gower Streets, London WC1.

2Present address: Radiation Evaluation and Exposure Laboratory National Naval Medical Center, Bethesda, Maryland, 20014, USA.

Received for publication 25 January 1972.
}

On physical examination seven were noted to have enlarged spleens; another had had a splenectomy for 'hypersplenism'. The data from the seven patients with clinically enlarged spleens and the remaining six were analysed separately. The seven control subjects with cirrhosis had the diagnosis established by liver biopsy. All were males ranging in age from 40 to 53. All but two had abnormalities in routine liver function tests, but none was icteric or had evidence of neurological or renal dysfunction. All seven had enlarged spleens (Table I). The 13 normal controls were all young adults (nine males, four females) who had no disease or condition related to the hepatic or haematological systems In all the livers and spleens were not palpable and the liver was of normal size by percussion. Standard liver function tests were also normal.

\section{STUDY PROCEDURE}

The techniques of Gray and Sterling (1950) and Crispell, Porter, and Nieset (1950) were modified to determine simultaneously the red cell mass and plasma volume using $40 \mu \mathrm{Ci} \mathrm{Na}_{2} \mathrm{Cr}^{51} \mathrm{O}_{4}$ and $5 \mu \mathrm{Ci}$ ${ }^{125}$ I-labelled human serum albumin (RISA ${ }^{1}$ ). Blood samples were drawn at $10,20,30$, and 60 minutes to determine red cell mass and plasma volume and three times a week for three weeks to determine survival half-time of ${ }^{51} \mathrm{Cr}$-labelled RBCs. Standards for the ${ }^{51} \mathrm{Cr}$-labelled RBCs and ${ }^{125}$ I-RISA were made following a standard dilution procedure. Samples each of $3 \mathrm{ml}$ of whole blood $\left({ }^{51} \mathrm{Cr}\right)$, plasma

${ }^{1}$ Rachromate-51 and RISA-125, Abbott Laboratories, North Chicago, III. 


\begin{tabular}{|c|c|c|c|c|c|c|c|c|c|c|c|c|c|}
\hline \multirow[t]{2}{*}{ Subject } & \multirow[t]{2}{*}{ Age } & \multirow[t]{2}{*}{$\operatorname{Sex}$} & \multicolumn{2}{|c|}{ Clinical Symptoms } & \multirow{2}{*}{$\begin{array}{l}K-F \\
\text { Rings }\end{array}$} & \multirow{2}{*}{$\begin{array}{l}\text { Spleen } \\
\text { Enlarge- } \\
\text { ment }^{1}\end{array}$} & \multicolumn{2}{|c|}{ Caeruloplasmin } & \multicolumn{3}{|l|}{ Copper } & \multirow[t]{2}{*}{$B S P(\%)$} & \multirow{2}{*}{$\begin{array}{l}\text { Bilirubin } \\
(\mathrm{mg} / \\
100 \mathrm{ml})\end{array}$} \\
\hline & & & $\begin{array}{l}\text { Neuro- } \\
\text { logical }\end{array}$ & Hepatic & & & $\begin{array}{l}\text { Ravin } \\
\text { Units }\end{array}$ & $\begin{array}{l}m g / 100 \\
m l)^{2}\end{array}$ & $\begin{array}{l}\text { Serum } \\
(\mu g / 100 \\
m l)\end{array}$ & $\begin{array}{c}\text { Urine } \\
(u g / d)\end{array}$ & $\begin{array}{l}\text { Hepatic } \\
\text { ( } \mu \mathrm{g} / \mathrm{g} \text { dry } \\
\text { tissue) }\end{array}$ & & \\
\hline \multicolumn{14}{|c|}{ Patients with Wilson's Disease without Enlarged Spleens } \\
\hline WRC & 25 & $\mathbf{M}$ & - & - & $+\rightarrow-$ & $\mathbf{0}$ & 0.022 & $5 \cdot 0$ & 24 & 99 & & 32 & 0.8 \\
\hline LCJ & 23 & $\mathbf{M}$ & - & - & + & $\mathbf{0}$ & 0.020 & $5 \cdot 8$ & 34 & 102 & 283 & 3 & $1 \cdot 5$ \\
\hline TPO & 11 & $\mathbf{F}$ & - & - & - & 0 & 0.075 & 5.0 & 53 & 350 & & 10 & 0.9 \\
\hline CIT & 48 & $\mathbf{M}$ & + & - & + & 0 & 0.057 & $8 \cdot 7$ & 60 & 729 & & 13 & 0.5 \\
\hline KSH & 14 & $\mathbf{M}$ & + & - & -1 & 0 & 0.021 & $5 \cdot 0$ & 34 & 80 & & 0 & $0 \cdot 1$ \\
\hline \multicolumn{14}{|c|}{ Patients with Wilson's Disease with Enlarged Spleens } \\
\hline SPC & 11 & $\mathbf{F}$ & - & - & + & \pm & 0.025 & $7 \cdot 1$ & 53 & 412 & & 35 & $2 \cdot 1$ \\
\hline HYH & 14 & $\mathbf{F}$ & + & - & + & \pm & 0.053 & $5 \cdot 5$ & 49 & 500 & & 5 & 0.8 \\
\hline SFL & 17 & $\mathbf{F}$ & + & - & + & 1 & 0.032 & $5 \cdot 0$ & 33 & 346 & & 5 & 0.8 \\
\hline CCL & 12 & $\mathbf{F}$ & - & - & $+\rightarrow-$ & 1 & 0.021 & $4 \cdot 0$ & 16 & 264 & 315 & 15 & $1 \cdot 8$ \\
\hline SCI & 18 & $\mathbf{M}$ & - & - & + & 5 & 0.075 & $13 \cdot 5$ & 49 & 527 & 164 & 15 & $1 \cdot 3$ \\
\hline CSS & 29 & $\mathbf{F}$ & + & + & + & 9 & 0.025 & $5 \cdot 0$ & 25 & 361 & 190 & 2 & 1.8 \\
\hline \multicolumn{14}{|c|}{ Patients with Cirrhosis of Liver } \\
\hline $\mathbf{Y H}$ & 42 & $\mathbf{M}$ & - & + & - & \pm & 0.321 & & & & & 42 & 1.4 \\
\hline TCK & 41 & $\mathbf{M}$ & - & - & - & \pm & 0.284 & $34 \cdot 0$ & & & & 31 & \\
\hline TCT & 44 & $\mathbf{M}$ & - & + & - & 3 & 0.317 & 52.0 & & & & 5 & $1 \cdot 3$ \\
\hline YTH & 47 & $\mathbf{M}$ & - & + & - & 4 & & & & & & 16 & 0.9 \\
\hline CTS & 53 & $\mathbf{M}$ & - & + & - & 5 & & & & & & 17 & $1 \cdot 3$ \\
\hline FYP & 40 & $\mathbf{M}$ & - & + & - & 5 & 0.297 & $54 \cdot 0$ & & & & 41 & 0.7 \\
\hline TSC & 46 & $\mathbf{M}$ & - & + & - & 6 & 0.378 & $25 \cdot 4$ & & & & 5 & $1 \cdot 1$ \\
\hline \multicolumn{14}{|c|}{ Normal Values } \\
\hline $\begin{array}{l}\text { Mean } \\
\pm \text { SD }\end{array}$ & & & - & & - & 0 & $\begin{array}{l}0.404 \\
0.084\end{array}$ & $\begin{array}{r}27 \cdot 5 \\
8 \cdot 3\end{array}$ & $\begin{array}{r}110 \cdot 2 \\
17 \cdot 3\end{array}$ & $\begin{array}{l}0.035 \\
0.020\end{array}$ & $\begin{array}{l}26 \cdot 8 \\
12 \cdot 8\end{array}$ & $<6$ & $\begin{array}{l}0.8 \\
0.5\end{array}$ \\
\hline
\end{tabular}

Table I Clinical and biochemical findings in subjects

${ }^{1}$ Enlargement in cm below LCB at AAL, $\pm=$ enlargement by percussion only. 'Immunological determination with Hyland immunoplates.

sPatient with splenectomy

$\left({ }^{125} \mathrm{I}\right)$, and standards were counted sufficiently long in a 3 in. $\times 3$ in. $\mathrm{NaI}(\mathrm{tl})$ well-type scintillation detector connected to a three-channel gamma-ray spectrometer to give less than $3 \%$ relative error with $95 \%$ confidence levels. Discriminator settings were chosen so that ${ }^{51} \mathrm{Cr}$ was counted without interferences from ${ }^{125} \mathrm{I}$ and a correction could be made for the contribution of ${ }^{51} \mathrm{Cr}$ counts at the ${ }^{125} \mathrm{I}$ setting. Plasma volume was calculated from the extrapolated time zero ${ }^{125}$ I count rate of the 10-, 20-, 30-, and 60 minute samples while the red cell mass was calculated from the average of the 20 - and 30 -minute ${ }^{51} \mathrm{Cr}$ whole blood count rates. Red cell mass was determined in all subjects while plasma volume was determined in 24 of the 33 subjects. Each subject also had external monitoring over the spleen with a 2 in. $\times 2$ in. $\mathrm{NaI}(\mathrm{tl})$ scintillation probe for 18 to 25 days to determine if the spleen were sequestrating RBCs. The external probe counts were corrected for decay, the curve obtained during the first two hours was extrapolated to zero time $\left(\mathrm{CPM}_{0}\right)$, and all subsequent counts (CPM) were expressed as the ratio of $\mathrm{CPM} / \mathrm{CPM}_{0}$. The ratios of the counts (CPM/ $\mathrm{CPM}_{0}$ ) were averaged by weeks for each subject and results from patients with Wilson's disease and cirrhosis were compared with results obtained in the controls.
Splenic enlargement by palpation was graded in centimetres below the left costal margin at the anterior axillary line with the patient supine. The method of Castell (1967) was used to detect splenic enlargement by percussion only.

\section{Results}

\section{ROUTINE HAEMATOLOGICAL FINDINGS}

Patients with Wilson's disease and patients with cirrhosis had lower haematocrits, white cell counts, and platelet counts than controls (Table II). These reductions were greatest in the patients with the largest spleens.

\section{BLOOD VOLUME STUDIES}

Red cell mass was higher in all patient groups than in the normal controls of the same sex (Table 1I). Plasma volume was greater in all patient groups than in the normal control group, but only two of the seven patients with Wilson's disease and splenic enlargement had the plasma volume determined. As expected, total blood volume was also greater in all patient groups than in the normal control group. The body haematocrit : peripheral haematocrit ratio was significantly higher in the patients with Wilson's 


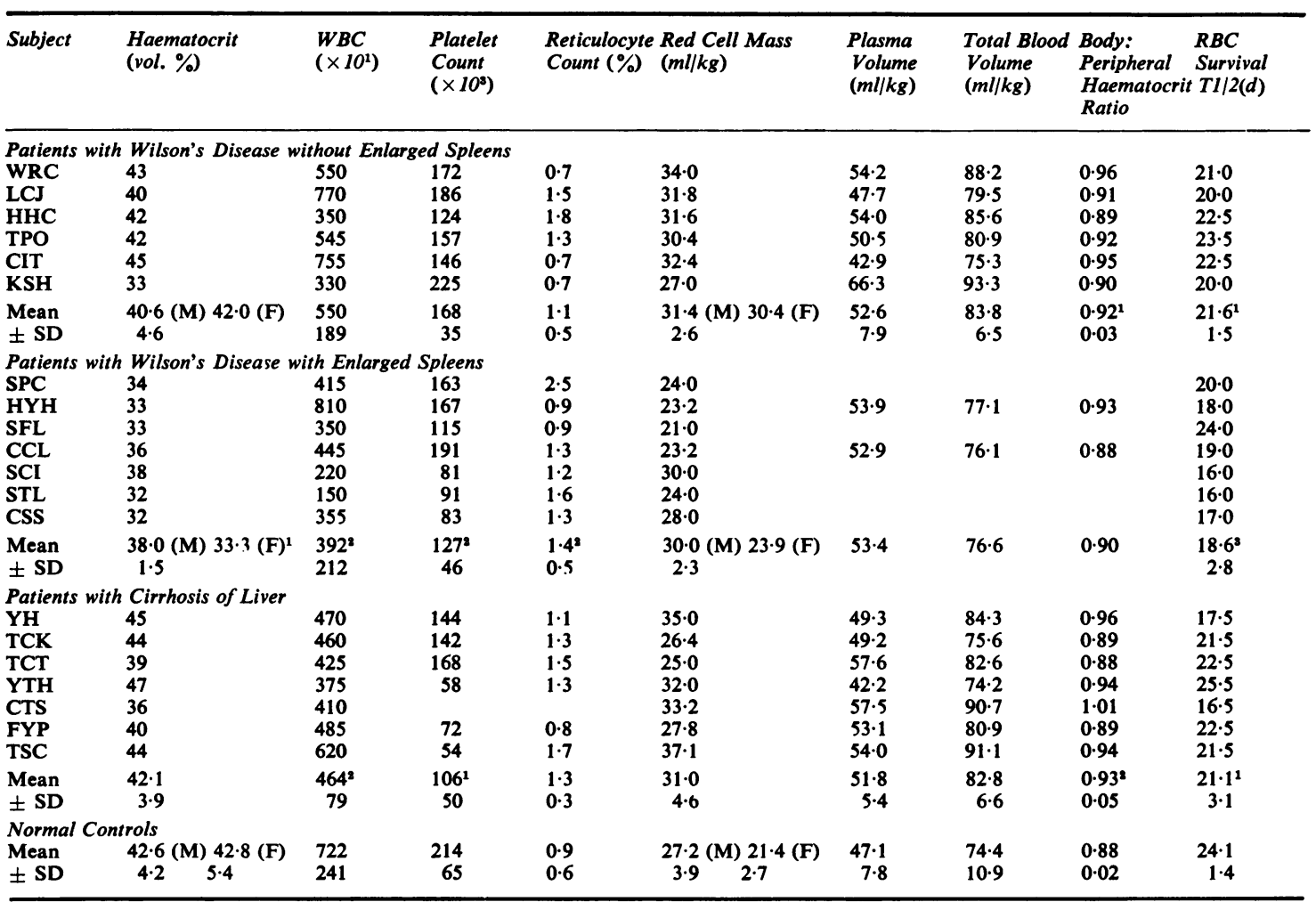

Table II Haematological findings in subjects

Significantly differ from normal controls: ${ }^{1} \mathrm{P}<0.01,{ }^{2} \mathrm{P}<0.05,{ }^{3} \mathrm{P}<0.001$.

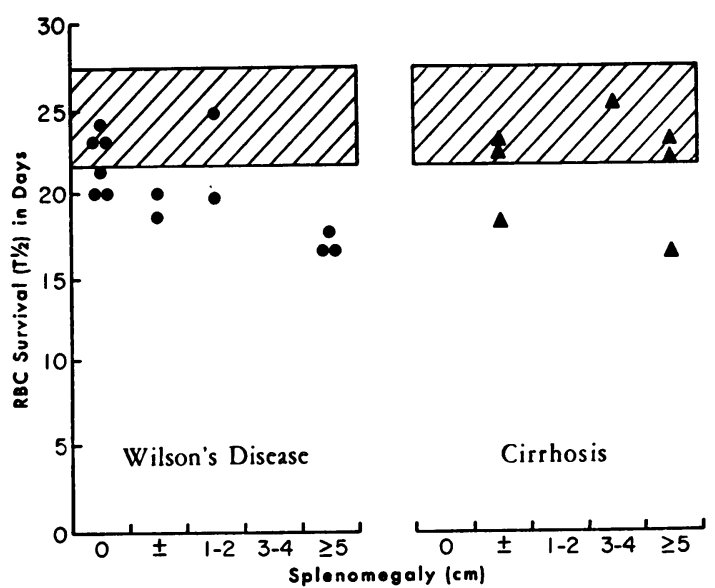

Fig. 1 Chromium-51 red blood cell survival times in patients with Wilson's disease and cirrhosis according to splenic enlargement. Shaded area represents the mean $\pm 2 S D$ in normal controls. disease and in the controls with cirrhosis than in the normal controls (Table II).

RBC SURVIVAL

Both groups of patients with Wilson's disease and the cirrhotics had significantly shorter RBC survival times than did normal control subjects (Table II). Patients with the largest spleens had the shortest survival times (Fig. 1).

\section{SPLENIC SEQUESTRATION}

Figure 2 shows the results of external probe counting over the spleen in patients with Wilson's disease and cirrhosis as the ratio of later counts to initial counts. Evidence of trapping of RBCs by the spleen in either group was not demonstrated.

\section{MISCELLANEOUS TESTS}

Serum bilirubin levels were elevated in only two of the patients with Wilson's disease and in none of the cirrhotics (Table I). These two patients also had abnormal BSP excretion and one (S.P.C.) was the 


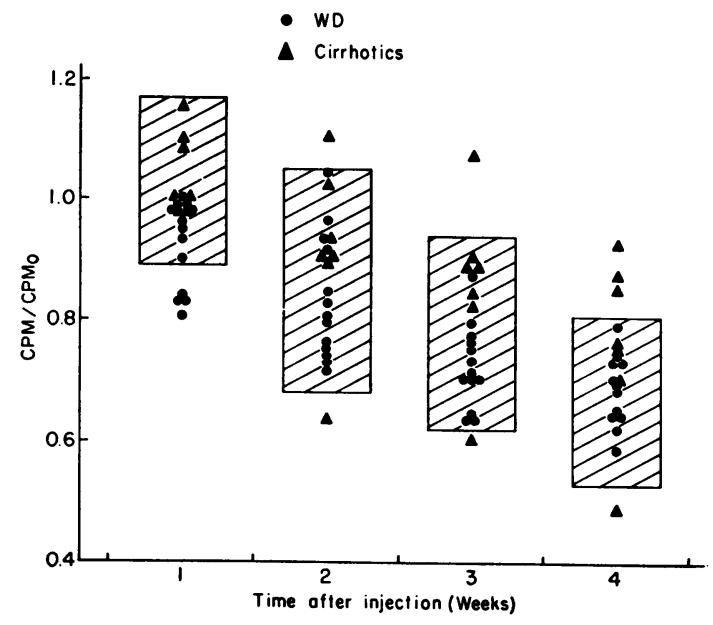

Fig. 2 Counting over the spleen in patients with Wilson's disease and cirrhosis in weeks after injection of ${ }^{51} \mathrm{Cr}$-labelled red cells. The average count for each week $(C P M)$ is compared with the initial counts $\left(C P M_{0}\right)$. The shaded areas represent mean $\pm 1 S D$ in normal controls.

only subject who had a raised reticulocyte count. Guaiac tests for faecal occult blood were negative in all subjects tested. Bone marrow aspirates were performed upon four patients with Wilson's disease and showed normal cellular morphology except for minimal erythroid hyperplasia in one case.

\section{Discussion}

The present study demonstrates the findings of 'hypersplenism' in Wilson's disease. The most severe reductions in haematocrits, white cell and platelet counts, and ${ }^{51} \mathrm{Cr}$-tagged red blood cell survivals occurred in the patients with the largest spleens (Table II, Fig. 1), but the six patients with Wilson's disease without detectable splenomegaly (including H.H.C. who had had a splenectomy) also had similar abnormalities. Thus, the findings typical of hypersplenism do not necessarily require the presence of a palpable spleen. We have no direct evidence to suggest the mechanism of hypersplenism in these individuals.

The cause of the decreased RBC survival is not clear. Increased elution of ${ }^{51} \mathrm{Cr}$ from the labelled RBCs has been shown not to occur in cirrhosis (Cawein, Hagedorn, and Owen, 1960; Pitcher and Williams, 1963). Furthermore, workers using the Ashby technique (Chaplin and Mollison, 1953; Jandl, 1955) have also shown reduced RBC survival in cirrhosis. Blood loss into the gut is unlikely since our subjects had negative tests for faecal occult blood.
Chromium-51 RBC survivals in the patients with Wilson's disease were only slightly longer than those reported by Katz, Velasco, Guzmán, and Alessandri (1964) (mean T1/2 of 17.4 days) in 13 patients with alcoholic cirrhosis whose liver function was more severely disturbed. Richmond, Donaldson, Williams, Hamilton, and Hutt (1967) found marked reductions in ${ }^{51} \mathrm{Cr} \mathrm{RBC}$ survival in 15 patients from Uganda with splenomegaly of unknown cause. These patients, like our patients with Wilson's disease, did not have evidence of splenic sequestration as manifested by a rise in spleen radioactivity. Like our patients, those of Richmond and his colleagues had anaemia, leucopenia, and thrombocytopenia; the red cell mass was greater than the haematocrit would suggest but was accompanied by an even larger increase in plasma volume. Others (Bateman, Shorr, and Elgvin, 1949; McFadzean and Todd, 1967; Pryor, 1967) also noted a hypervolaemia with reduced peripheral haematocrit but normal red cell mass in splenomegaly of various causes. This is usually associated with an increase in the body: peripheral haematocrit ratio as was noted in some of our patients.

McIntyre and his associates (1967) reported acute haemolytic episodes with shortened RBC survival in three patients with Wilson's disease and splenomegaly. They failed to note increased activity of ${ }^{51} \mathrm{Cr}$ over the spleen and believed that white blood cells and platelet counts gave no suggestion of hypersplenism. They proposed that the haemolysis in their patients was caused by a sudden release of copper from the tissues into the blood; Cartwright, Hodges, Gubler, Mahoney, Daum, Wintrobe, and Bean (1954) speculated in similar terms. More recently the latter group (Deiss, Lee, and Cartwright, 1970) suggested, after carefully studying the haemolysis of a patient with Wilson's disease with splenomegaly, that the haemolytic anaemia was due to increased oxidative stress on the erythrocytes as a consequence of the accumulation of copper within the cells. This mechanism could well explain the sudden episodes of jaundice which occur in patients with Wilson's disease, often before the onset of other symptoms.

More frequently, in our experience, a mild anaemia was associated with hypersplenism. This was both dilutional (increased plasma volume and pooling of RBCs in the spleen) and associated with decreased RBC survival. This haemolytic component was supported by the finding of gallstones containing bile pigment at operation in one patient (H.H.C.) and in two of three (S.T.L. and C.C.F.) other patients with Wilson's disease at postmortem examination. The mechanism of the hypersplenism

${ }^{1}$ Not included in present study. 
is obscure, but it does not appear to differ from hypersplenism in patients with cirrhosis of other aetiologies.

This investigation was supported by the Bureau of Medicine and Surgery, work units MR005.09-0040A and T.002.

Dr P. J. S. Hamilton reviewed the data, Mrs Betty Gray provided secretarial assistance, and Mr Dixon Chen provided technical assistance.

The opinions or assertions contained herein are those of the authors and are not to be construed as official or reflecting the views of the US Navy Department or the Naval Service at large.

Reprint requests to Publications Editor, NAMRU2, Box 14, APO San Francisco 96263, USA.

References

Bateman, J. C., Shorr, H. M., and Elgvin, T. (1949). Hypervolemic anemia in cirrhosis. J. clin. Invest., 28, 539-547.

Cartwright, G. E., Hodges, R. E., Gubler, C. J., Mahoney, J. P., Daum, K., Wintrobe, M. M., and Bean. W. B. (1954). Studies on copper metabolism. XIII. Hepatolenticular degeneration. $\boldsymbol{J}$. clin. Invest., 33, 1487-1501.
Castell, D. O. (1967). The spleen percussion sign. A useful diagnostic technique. Ann. intern. Med., 67, 1265-1267.

Cawein, M. J., III, Hagedorn, A. B., and Owen, C. A., Jr. (1960). Anemia of hepatic disease studied with radiochromium. Gastroenterology, 38, 324-331.

Chaplin, H., Jr., and Mollison, P. L. (1953). Red cell life-span in nephritis and in hepatic cirrhosis. Clin. Sci., 12, 351-360.

Crispell, K. R., Porter, B., and Nieset, R. T. (1950). Studies of plasma volume using human serum albumin tagged with radioactive $\mathrm{I}^{131}$. J. clin. Invest., 29, 513-516.

Deiss, A., Lee, G. R., and Cartwright, G. E. (1970). Hemolytic anemia in Wilson's disease. Ann. intern. Med., 73, 413-418.

Gray, S. J., and Sterling, K. (1950). Determination of circulating red cell volume by radioactive chromium. Science, 112, 179-180.

Jandl, J. H. (1955). The anemia of liver disease. Observations on its mechanism. J. clin. Invest., 34, 390-404.

Katz, R., Velasco, M., Guzmán, C., and Alessandri, H. (1964). Red cell survival estimated by radioactive chromium in hepatobiliary disease. Gastroenterology, 46, 399-404.

McFadzean, A. J. S., and Todd, D. (1967). The blood volume in post, necrotic cirrhosis of the liver with splenomegaly. Clin. Sci., 32, 339-350.

McIntyre, N., Clink, H. M., Levi, A. J., Cumings, J. N., and Sherlock, S. (1967). Hemolytic anemia in Wilson's disease. New Engl. J. Med., 276, 439-444.

Pitcher, C. S., and Williams, R. (1963). Reduced red cell survival in jaundice and its relation to abnormal glutathione metabolism. Clin. Sci., 24, 239-252.

Pryor, D. S. (1967). The mechanism of anaemia in tropical splenomegaly. Quart. J. Med., 36, 337-356.

Richmond, J., Donaldson, G. W. K., Williams, R., Hamilton, P. J. S., and Hutt, M. S. R. (1967). Haematological effects of the idiopathic splenomegaly seen in Uganda. Brit. J. Haemat., 13, 348363. 